\title{
Doing Too Little or Too Much? Private Law Before the European Court of Human Rights
}

\author{
Jan Zglinski*
}

\section{Introduction}

The question as to whether fundamental rights impose duties on private individuals is as much an old constitutional chestnut as it is a controversial current affair. Can a hotel owner deny hosting the member of a neo-Nazi party? ${ }^{1}$ Can a devout Christian baker refuse to make a cake for a same-sex wedding? ${ }^{2}$ Can a company dismiss a Muslim employee because she refuses to take her headscarf off at work? ${ }^{3}$ At the heart of these cases lies the issue whether private behaviour should be bound by fundamental rights, a problem legal doctrine calls horizontal effect. Courts across the globe have, in different ways and to different extents, recognised such an effect. They have thereby changed the rights and obligations private individuals hold towards each other. By the same token, they have changed private law as such. Private law no longer is an autonomous domain, insulated from external pressures. As its making and application are put under constitutional control, it has become, just like other legal fields, an area of 'applied constitutional law'.4

The phenomenon of horizontal effect or, more generally speaking, of the constitutionalisation of private law has been widely debated. Yet, most of the discussion has been set in the national context. ${ }^{5}$ Only more recently, the constitutionalisation of European private law has made it onto

\footnotetext{
* Erich Brost Lecturer, University of Oxford and St. Hilda's College. The author warmly thanks Hans Micklitz for the nudge to tackle this topic and the manifold help along the way, Barbara Warwas for sharing her findings on the ECtHR as well as Barend Van Leeuwen and the anonymous referees for insightful comments. The research leading to these results has received funding from the European Research Council under the European Union's Seventh Framework Programme (FP/2007-2013) / ERC Grant Agreement no. 269722.

${ }^{1}$ BGH, Udo Voigt (V ZR 115/11), 9 March 2012. For a similar, more recent example involving the German far-right party Alternative für Deutschland, see <https://www.zeit.de/politik/deutschland/2018-06/afdparteitag-augsburg-hotels-stornieren-buchungen $>$.

2 U.S. Supreme Court, Masterpiece Cakeshop v. Colorado Civil Rights Commission, 584 U.S. __. See also Leev Ashers Baking Co Ltd \& Ors [2015] NICty 2, where a Northern-Irish baker chose not to bake a cake carrying the slogan 'support gay marriage'.

3 ECJ, Case C-188/15 Bongnaoui [2017] ECR I-0000 and Case C-157/15 Achbita [2017] ECR I-0000.

${ }^{4}$ Mattias Kumm, Who is Afraid of the Total Constitution? Constitutional Rights as Principles and the Constitutionalization of Private Law' (2006) 7 German Law Journal 341, at 359.

${ }^{5}$ For a small selection see: Jörg Fedtke and Dawn Oliver (eds), Human Rights and the Private Sphere (Routledge 2007); Chantal Mak, Fundamental Rights in European Contract Law: A Comparison of the Impact of Fundamental Rights on Contractual Relationships in Germany, the Netherlands, Italy and England (Wolters Kluwer 2008); David Hoffman (ed.), The Impact of the UK Human Rights Act on Private Law (Cambridge University Press 2011).
} 
the scholarly agenda. Here, the focus has so far predominantly been on the European Union law. ${ }^{6}$ Ever since the 1970s, the European Court of Justice (ECJ) has accepted that certain economic rights, notably the freedoms of movement and the right to equal pay, could be invoked against private entities. ${ }^{7}$ Subsequent decades brought a growth of constitutional input on private law from the Luxembourg judges, partly as a result of the growth of EU private law itself. This has affected policy fields ranging from consumer protection, ${ }^{8}$ to financial services, ${ }^{9}$ to labour law, ${ }^{10}$ which all have come to be infused with constitutional reasoning and rationale.

Less attention has been paid to the other European court, the European Court of Human Rights (ECtHR). ${ }^{11}$ A body exclusively created for fundamental rights control, it may not seem naturally predisposed to deal with, or even receive, questions from private law. Yet, largely unnoticed, the Strasbourg Court has developed an extensive private law jurisprudence over the years. It has decided conflicts between employers and employees, heirs and testators, patients and doctors. In this way, it has made a distinct contribution to the constitutionalisation process of European private law.

\footnotetext{
${ }^{6}$ Oliver Gerstenberg, 'Private Law and the New European Constitutional Settlement' (2004) 10 European Law Journal 766; Stefan Grundmann (ed), Constitutional Values and European Contract Law (Wolters Kluwer 2008); Norbert Reich, 'The Public/Private Divide in European Law' in Micklitz and Caffagi (eds.), European Private Law after the Common Frame of Reference (Edward Elgar 2010) 56; Loïc Azoulai, 'Sur un sens de la distinction public/privé dans le droit de l'Union européenne' (2010) 46 Revue trimestrielle de droit européen 842; Mirjam de Mol, 'The Novel Approach of the ECJ on the Horizontal Direct Effect of the EU Principle of NonDiscrimination' (2011) 18 Maastricht Journal of European and Comparative Law 109; Hans Micklitz (ed), The Constitutionalization of European Private Law (Oxford University Press 2014).

${ }^{7}$ ECJ, Case 43/75 Defrenne (No. 2) [1976] ECR 455 and Case 36/74 Walrave [1974] ECR 1405.

${ }^{8}$ Oliver Gerstenberg, 'Constitutional Reasoning in Private Law - The Role of the ECJ in Adjudicating Unfair Terms in Consumer Contracts' (2015) 21 European Law Journal 599; Hans Micklitz, 'The Constitutional Transformation of Private Law Pillars Through the ECJ' in Collins (ed), European Contract Law and the Charter of Fundamental Rights (Intersentia 2017) 49.

${ }^{9}$ Olha Cherednychenko, 'Fundamental Rights, European Private Law, and Financial Services', in Micklitz (ed), The Constitutionalization of European Private Law (Oxford University Press 2014) 170.

${ }^{10}$ Mark Bell, 'Constitutionalization and EU Employment Law', in Micklitz (ed), The Constitutionalization of European Private Law (Oxford University Press 2014) 137.

${ }^{11}$ Andrew Clapham, 'The "Drittwirkung" of the Convention', in McDonald et al (eds.), The European System for the Protection of Human Rights (Martinus Nijhoff 1993) 163; Lech Garlicki, 'Relations between Private Actors and the European Convention on Human Rights', in Sajó and Uitz (eds.), The Constitution in Private Relations: Expanding Constitutionalism (Eleven 2005) 129; Tom Barkhuysen and Michiel Van Emmerik, 'Constitutionalisation of Private Law: The European Convention of Human Rights Perspective' in Barkhuysen and Lindenbergh (eds.), Constitutionalisation of Private Law (Martinus Nijhoff Publishers 2006) 43; Dean Spielmann, 'The European Convention on Human Rights: The European Court of Human Rights' in Oliver and Fedtke (eds.), Human Rights in the Private Sphere - A Comparative Study (Routledge 2007) 427. The ECtHR's private law jurisprudence is also addressed in Hugh Collins, 'On the (In)compatibility of Human Rights Discourse and Private Law' in Micklitz (ed), The Constitutionalization of European Private Law (Oxford University Press 2014) 39.
} 
This paper seeks to provide an overview of, and critically engage with, the ECtHR's jurisprudence on private law. The notion of private law is, for this purpose, understood broadly. It includes both legislation and case-law regulating private relations, substantial rights as well as the procedural rules necessary to enforce them. The paper proceeds as follows. I will begin by explaining to what extent private law falls under the scope of the ECHR and which doctrinal manoeuvres of the Strasbourg Court have made this possible (II.). I will, then, examine how far the ECtHR's involvement in private law matters goes in practice. This will include, for one thing, the question as to which private law matters the Court exercises scrutiny over (III.) and, for another, how it exercises this scrutiny, i.e. the issue of standards of review (IV.). A tension will become apparent. Despite having created far-reaching review powers in this area - akin to those of many powerful national constitutional courts -, the ECtHR interferes in national private law only rarely. Where, however, the Court chooses to get involved, it acts as a powerful corrective force. Two opposing objections can be raised against this approach: do the European judges do too little, by granting national authorities a wide margin of appreciation in most of their judgments (V.)? Or do they, to the contrary, do too much, by limiting private autonomy and subverting domestic regulatory choices in some cases (VI.)? The paper seeks to show that the ECtHR's stance constitutes an attempt to reconcile the constitutional principles underlying the Convention system and to do justice to the evolution of private law.

\section{Constructing (Strong Indirect) Horizontal Effect}

As most constitutions around the world, the ECHR does not expressly confront the issue of whether private individuals, or the laws governing them, are bound by its provisions. ${ }^{12}$ Article 1 only identifies the 'High Contracting Parties' as addresses of the Convention. In spite of this, the Strasbourg Court does exercise broad review powers over private law relations. Like so many other constitutional courts, it has found a way of extending the scope of fundamental rights to rules regulating private behaviour and even to certain private disputes, however without much of the doctrinal acrobatics that typically go along with it. ${ }^{13}$ The key to the ECtHR's jurisprudence lies in the distinction between negative and positive obligations. Whereas the former are engaged when a state actively impedes fundamental rights (by laws, acts, or court decisions), the latter are

\footnotetext{
${ }^{12}$ South Africa's Final Constitution of 1996 is one famous exception. Section 8(2) of the Bill of Rights states that it 'binds a natural or juristic person if, and to the extent that, it is applicable, taking account of the nature of the right and the nature of any duty imposed by the right.'

${ }^{13}$ Much ink has been spilled over the various ways in which supreme and constitutional courts have justified horizontal effect. For a good analysis see Stephen Gardbaum, "The "Horizontal Effect" of Constitutional Rights' (2003) 102 Michigan Law Review 387.
} 
triggered by a state's failure to sufficiently protect them. The Court's jurisdiction over private law, then, is the result of two doctrinal moves: first, a broadening of the ECHR's reach from negative to positive obligations and, second, an extensive reading of the notion of positive obligations. This creates three ways in which private law can come under the scope of the Convention.

The first are restrictive private law rules. This is the classical situation of negative obligations. A state adopts a measure regulating an individual's civil status or their relations with other individuals and thereby interferes with their fundamental rights. This can concern prohibitions from entering into certain relations, the duty to do so, or limitations on how the rights flowing from them can be enforced. Rules limiting the extent to which children born out of wedlock can inherit from their parents, ${ }^{14}$ forcing freeholders to sell their property to their leaseholders, ${ }^{15}$ and barring the possibility to claim compensation for medical negligence ${ }^{16}$ fall, to name some examples from the Court's case-law, into this category. Although fundamental rights restrictions here are most often the result of private law legislation, they can also be triggered by court decisions. ${ }^{17}$

Insufficiently protective (or inexistent) private law rules constitute a second category. Its theoretical basis lies in the doctrine of positive obligations. Positive obligations, also called protective duties, represent the idea that constitutional rights can require more from a state than just not to interfere. In order to provide an adequate level of protection, it sometimes must get active: regulate where there is no regulation, act where it had remained idle. The Strasbourg Court has affirmed positive obligations in this sense within and outside the field of private law. ${ }^{18}$ It has told Member States to legislate where there were gaps in the law, to create procedural mechanisms where none were in place, and to investigate where they had failed to. ${ }^{19}$ In private law, such duties have, for instance, been discussed regarding the need to adopt laws providing a stronger protection for individuals targeted by media coverage ${ }^{20}$ or to create procedural means allowing

\footnotetext{
${ }^{14}$ ECHR, Marckx v. Belgium App no 6833/74 (13 June 1979).

${ }^{15}$ ECHR, James and Others v. UK App no 8793/79 (21 February 1986).

${ }^{16}$ ECHR, Draon v. France App no 1513/03 (6 October 2005).

17 ECHR, Von Hannover v. Germany App no 59320/00 (24 June 2004); Palomo Sanchez and Others v. Spain App nos. 28955/06 et al. (12 September 2011).

${ }^{18}$ See Matthias Klatt, 'Positive Obligations under the European Convention on Human Rights' (2011) Zeitschrift für ausländisches öffentliches Recht und Völkerrecht 691.

${ }^{19}$ ECHR, $X$ and Y v. The Netherlands App no 8978/80 (26 March 1985); Plattform "Ärzte für das Leben" v. Austria App no 10126/82 (21 June 1988); Hatton App no 36022/97 (2 October 2001).

${ }^{20}$ ECHR, Mosley v. UK App no 48009/08 (10 May 2011).
} 
to compel an alleged father to undergo a DNA test. ${ }^{21}$ These are, if you will, 'genuine' positive obligations.

Yet, the Court does more under the label of positive obligations, and it is this surplus which forms the source for a third category of private law cases which is both the broadest and most controversial. Where national courts confirm or give effect to private bebaviour restricting fundamental rights, this act of confirmation can be challenged before the ECtHR. Pla and Puncernau v. Andorra illustrates this option. ${ }^{22}$ The case concerned a private dispute about a testament that contained, on the reading of the national courts, a clause that limited inheritance to biological children (thereby excluding adopted ones). The Court clarified at the outset that it was 'not in theory required to settle disputes of a purely private nature'. ${ }^{23}$ However, it could not 'remain passive' where a national court's interpretation of a legal act ran against the principles of the ECHR, even where this act was a private testament or contract. Based on the positive obligations doctrine, ${ }^{24}$ the Court concluded that the applicant's rights from Articles 14 and 8 ECHR were violated. The idea of positive obligations here differs from what were called 'genuine' positive obligations earlier. It was not a gap in Andorran private law or the idleness of the domestic judiciary the Court took issue with. It was the fact that the state, through its institutional apparatus, validated private behaviour - a discriminatory testament - which violated fundamental rights. Call this 'extended' positive obligations. ${ }^{25}$ Conceptually, the Court's terminology may be misleading as it confounds two scenarios: an individual's right being impeded because of the state's inactivity (genuine positive obligation) and an individual's right being impeded because of another individual's behaviour which is merely enforced by the national judiciary (extended positive obligations). Doctrinally, however, this approach has a virtue: it makes things simple. It means that every private dispute ending up before a domestic court can, in principle, fall under the ECHR, as long as there is a material connection with the scope of a Convention right. ${ }^{26}$ National courts become, if you will, a type of King Midas. Whatever they touch falls into the Strasbourg Court's jurisdiction.

\footnotetext{
${ }^{21}$ ECHR, Mikulić v. Croatia App no 53176/99 (7 February 2002).

22 ECHR, Pla and Puncernau v. Andorra App no 69498/01 (13 July 2004).

23 ibid., para 59.

24 ibid., para 62.

${ }^{25}$ Note that, structurally, this scenario is closer to the idea of negative than to that of positive obligations because it is the state authority's action (the national court's judgment) that triggers the fundamental rights violation. One could therefore also call it 'extended' negative obligations.

${ }^{26}$ ECHR, Botta v. Italy App no. 153/1996/772/973 (24 February 1998).
} 
Regardless of which of the three categories a private law case falls into, the consequence is always the same: the Court exercises proportionality analysis. ${ }^{27}$ It checks whether the aims for interfering into the applicant's right(s) were legitimate, less intrusive measures would have existed, and if an adequate balance between the relevant concerns was struck. Formally, the object of this scrutiny is the given state action - the restrictive rule, the lack of protective regulation, or the validation of private behaviour. This is the result of the manner in which the Court has constructed the ECHR's scope over private law: in all three scenarios, the focus lies on the duties of the state towards the individual, not of individuals towards each other. In substance, however, the Court often goes further than this. It examines whether the private behaviour underlying the dispute constitutes a disproportionate restriction on an individual's fundamental rights. (A phenomenon which can be attributed to, and further demonstrates, the structural similarity between direct and indirect effect. ${ }^{28}$ ) Where, for instance, an employee is dismissed because an examination of his yahoo messenger history revealed that he was chatting with his fiancée during work hours (Barbulescu v. Romania), ${ }^{29}$ the ECtHR does not only review whether the domestic court has struck an adequate balance between the rights and concerns at stake. It checks whether the employer had a legitimate interest to verify that his employees were completing their professional tasks while at work, if its surveillance of the employee's communication was overly intrusive, whether private details were revealed, and so on. The question is 'does one person's behaviour restrict another person's rights disproportionately?', not just 'did the national courts exercise a satisfactory proportionality analysis?'.

The ECtHR's reach over private law matters roughly corresponds to what Stephen Gardbaum, analysing the U.S. system, has coined 'strong indirect' horizontal effect. ${ }^{30}$ Although private behaviour in itself cannot be challenged under the Convention - there is no such thing as direct horizontal effect -, all laws and acts governing private behaviour can. Every provision regulating civil status or private relations, no matter if constitutional, statutory, or judge-made, must be compatible with fundamental rights. Note that this creates a broader potential for applying fundamental rights to private law than in many other legal orders. The Canadian Supreme Court

${ }^{27}$ ECHR, Von Hannover (No. 2) App nos. 40660/08 and 60641/08 (7 February 2012), para 99. See also ECHR, $X, Y$ and $Z v$. UK App no 21830/93 (22 April 1997), para 41; Draon v. France (n 13), para 105. This may also be the reason why the Court, in some cases, does not even settle which type of obligation, negative or positive, a case turns on; see Hatton (n 16), para 119.

28 See Kumm, 'Who is Afraid of the Total Constitution?' (n 4) 352 et seq.; Hugh Collins, 'On the (In)compatibility of Human Rights Discourse and Private Law' in Micklitz (ed), The Constitutionalization of European Private Law (Oxford University Press 2014) 39.

${ }^{29}$ ECHR, Barbulescu v. Romania App no 61496/08 (12 January 2016).

${ }^{30}$ Gardbaum (n 10). 
restricts the function of fundamental rights to the development of (judge-made) common law. ${ }^{31}$ The German Bundesverfassungsgericht, although emphasising that fundamental rights permeate the entire legal order, states that their foremost role lies in helping with the interpretation of the general clauses of the civil code. ${ }^{32}$ The European Court of Justice applies EU free movement rights directly against private parties, but, as a rule, only if they have regulatory or quasi-regulatory powers. ${ }^{33}$ The Inter-American Court of Human Rights has, in a similar vein, for a long time limited the horizontal effect of fundamental rights to potent private groups, such as militias and paramilitary organisations. ${ }^{34}$ The Strasbourg Court's jurisprudence does not foresee any of these limitations. The ECHR can, in principle, be applied to judicially and legislatively made private law, to precise and open-ended clauses, to disputes involving parties with and without special regulatory powers. There is no private law matter which would - because of the type of law or defendant - be categorically exempted from fundamental rights scrutiny.

\section{The ECHR and Private Law in Action I: Scope of Application}

Notions such as negative/positive obligations or direct/indirect horizontal effect describe the theoretical relationship of fundamental rights with and influence over private law. In order to understand the practical effect of the ECHR, one must look into how far this potential is realised. The ECtHR rendered its first judgments on private law already in the 1980s. ${ }^{35}$ But it is the past decade which has brought a veritable explosion of private law adjudication before the Strasbourg Court. ${ }^{36}$ How far does the Court's private law jurisprudence reach? Although its case-law covers a broad range of areas, three stand out: family law, labour law, and press law.

\footnotetext{
${ }^{31}$ Canadian SC, Retail, Wholesale \& Dep't Store Union v. Dolphin Delivery Ltd. [1986] 2 S.C.R. 573.

32 BVerfGE 7, 198 (Lüth); BVerfGE 89, 214 (Bürgschaftsverträge).

33 This notably includes trade unions and professional bodies; see ECJ, Walrave (n 7); Case C-415/93 Bosman [1995] ECR I-4921; Case C-438/05 Viking Line [2007] ECR I-10779. There is one famous exception: in what has thus far remained an isolated decision, the Court has affirmed the possibility for a jobseeker to rely on the free movement of workers against a private bank; Case C-281/98 Angonese [2000] ECR I-04139. Outside the realm of free movement law, the Court has accepted that the right of equal pay and the principle of equal treatment can also be relied on against private entities without such regulatory powers; see Defrenne (No. 2) (n 7) and Case C-144/04 Mangold [2005] ECR I-9981.

${ }^{34}$ IACtHR, Comunidad de Paz de San José de Apartadó v. Colombia (18 June 2002). For an overview of the case-law development in this area, see Javier Mijangos y González, 'The doctrine of the Drittwirkung der Grundrechte in the case law of the Inter-American Court of Human Rights' (2008) InDret 1.

${ }^{35}$ ECHR, Young, James and Webster v. UK App nos. 7601/76 and 7806/77 (13 August 1981); James and Others (n 12).

${ }^{36}$ See the case-law cited in Sections II. through V.
} 
Family law forms the single largest group of private law cases before the Court. Judgments in this domain all turn on different aspects of Article 8, sometimes in connection with Article 14 ECHR. Parenthood is one important issue, with disputes ranging from the right to know one's mother, ${ }^{37}$ to the establishing of a child's biological father, ${ }^{38}$ to the question as to whether a female-to-male transsexual can be legally regarded as the father of a child. ${ }^{39}$ A second relevant topic is artificial insemination. Complaints brought before the Strasbourg judges have targeted state-imposed limitations on in vitro fertilisation ${ }^{40}$ or prohibitions of gestational surrogacy agreements. ${ }^{41}$ Frequently, family law litigation also touches on questions relating to antidiscrimination. This notably concerns rules discriminating on grounds of sexual orientation or sexual identity, for instance when it comes to adopting, ${ }^{42}$ renting apartments, ${ }^{43}$ or establishing parenthood. ${ }^{44}$ Two further, separate clusters of cases concern child abduction ${ }^{45}$ and limitations on the right to choose one's surname. ${ }^{46}$

Labour law is the second main application field. Here, the jurisprudence is not concentrated on a single ECHR provision but covers a series of Convention rights, including Article 6(1) ECHR (right to fair trail), Article 8 ECHR (right to privacy), as well as Articles 9 (right to free speech) and 10 ECHR (religious freedom). The majority of cases concern dismissals or disciplinary sanctions imposed on employees by their employers. ${ }^{47}$ The reason for these sanctions typically lies in certain forms of behaviour the employee exposed at work: the wearing of a cross despite the employer's religious neutrality policy, ${ }^{48}$ the use of company messaging services for private purposes ${ }^{49}$ or the publication of caricatures ridiculing the manager..$^{50}$ At times, however, it can also be behaviour outside the workplace that triggers the sanction, for example the employee's

${ }^{37}$ ECHR, Odièvre v. France App no 42326/98 (13 February 2003).

${ }^{38}$ ECHR, Mikulić (n 18); Mizzi v. Malta App no 26111/02 (12 January 2006).

${ }^{39} X, Y$ and $Z$ (n 24).

${ }^{40}$ ECHR, S.H. and Others v. Austria App no 57813/00 (3 November 2011).

${ }^{41}$ ECHR, Mennesson v. France App no 65192/11 (26 June 2014).

${ }^{42}$ ECHR, Frette v. France App no 36515/97 (26 February 2002).

${ }^{43}$ ECHR, Karner v. Austria App no 40016/98 (24 July 2003).

${ }^{44} X, Y$ and $Z v$. UK (n 24).

${ }^{45}$ ECHR, Neulinger and Sburuk v. Switzerland App no 41615/07 (8 January 2009); Sneersone and Kampanella v. Italy App no 14737/09 (12 July 2011); Raban v. Romania App no 25437/08 (26 October 2010); X v. Latvia App no 27853/09 (26 November 2013).

${ }^{46}$ ECHR, Burghartz v. Switzerland App no 16213/90 (22 February 1994); Cusan and Fazzo v. Italy App no 77/07 (7 January 2014).

47 A further, distinct group of cases turns on the enforceability of salary claims of embassy employees. Some Contracting Parties bar their access to justice on grounds of the international law doctrine of state immunity. See ECHR, Cudak v. Lithuania App no 15869/02 (23 March 2010); Wallishauser vs. Austria App no 156/04 (17 July 2012).

${ }^{48}$ ECHR, Eweida and Others v. UK App nos. 48420/10 (15 January 2013).

${ }^{49}$ Barbulescu (n 26).

${ }^{50}$ Palomo Sanchez (n 14). 
membership in a right-wing party, ${ }^{51}$ their H.I.V. positivity, ${ }^{52}$ or critical remarks about the company on a local radio station. ${ }^{53}$

Press law is the third central area of the ECtHR's private law jurisprudence. Cases here are often similar both on a factual and legal level. Factually, they usually concern conflicts between media outlets and the individuals these outlets report on, typically celebrities of some sort. Legally, this conflict is translated into a balancing act between the right to free speech (Article 10 ECHR) and the right to privacy (Article 8 ECHR). The essence of these cases is where to draw the line: how far can newspapers go in covering the private lives of celebrities? Where does the latters' protected private sphere begin? Examples of problems decided by the Court include whether states must adopt pre-notification requirements for magazines, ${ }^{54}$ which photos of a noble family's holidays can be published, ${ }^{55}$ and if the picture and name of a famous neo-Nazi can be broadcasted upon his release from prison. ${ }^{56}$

In spite of the high prevalence of the above fields in the Court's jurisprudence, there is a considerable number of individual cases relating to other areas of private law. Appleby v. UK deals with the question as to whether the owner of a private shopping mall should be made to tolerate an environmental protest on his premises. ${ }^{57}$ The already mentioned Pla and Puncernau v. Andorra turns on whether testators can discriminate in their wills. ${ }^{58}$ G.B. and R.B. v. Moldova and Draon v. France concern the possibility of claiming damages for medical negligence. ${ }^{59}$ Further examples exist, concerning matters ranging from property, ${ }^{60}$ to lease agreements ${ }^{61}$ to noise regulation. ${ }^{62}$

What is striking about this list is its breadth. The ECtHR has - despite the Council of Europe's lack of legislation, or even legislative competence, in this domain ${ }^{63}$ - adjudicated on a wide scope of private law matters, and continues doing so. Its reach manifests itself in two ways. First, the

\footnotetext{
${ }^{51}$ ECHR, Redfearn v. UK App no 47335/06 (6 November 2012).

52 ECHR, I.B. v. Greece App no 552/10 (3 October 2013).

${ }^{53}$ ECHR, García Mateos v. Spain App no 38285/09 (19 February 2013).

54 Mosley (n 17).

${ }_{55}$ ECHR, Von Hannover (n 14); Von Hannover (No 2) (n 24); Von Hannover (No 3) App no 8772/10 (19 September 2013).

${ }^{56}$ ECHR, Österreichischer Rundfunk v. Austria App no 35841/02 (7 December 2006).

${ }^{57}$ ECHR, Appleby and Others v. UK App no 44306/98 (6 May 2003).

58 Pla and Puncernau (n 19).

${ }^{59}$ ECHR, G.B. and R.B. v. Moldova App no 16761/09 (18 December 2012); Draon (n 13).

${ }^{60}$ ECHR, Pye v. UK App no 44302/02 (30 August 2007).

${ }^{61}$ James and Others (n 12); ECHR, Lindheim and Others v. Norway App nos. 13221/08 and 2139/10 (12 June 2012).

${ }^{62}$ Hatton (n 16).

63 This is, of course, a major difference with EU private law. The ECJ's private law jurisprudence is driven by EU harmonisation to an important extent.
} 
Court's jurisprudence covers a broad range of private law areas. We find, if with variations as to their prevalence, all main pillars of private law: contract, tort, property, succession, and family law. Second, it covers all private law dimensions. To use a distinction made famous by Walter van Gerven, ${ }^{64}$ the case-law touches on rights as much as it does on remedies and procedures. The ECtHR has not only decided on the existence and extent of claims of individuals towards each other (rights), it has determined through which means these claims can be enforced (remedies) ${ }^{65}$ and influenced how domestic courts ought to adjudicate disputes between private parties (procedures). ${ }^{66}$

\section{The ECHR and Private Law in Action II: Standards of Review}

The alarm bells of those not sympathetic to the idea of fundamental rights infiltrating into private law may be ringing. The ECtHR has not only created the theoretical possibility to shape wide parts of private law by giving Convention rights strong indirect horizontal effect, it also decides on numerous private law issues in practice. As a result, it has become the 'final arbiter' 67 in disputes between parents and children, employers and employees, patients and doctors. By the same token, it has acquired the authority to define the right balance in private relations between free speech and privacy, family life and social policy, the freedom to conduct one's business and to exercise one's religion. For some, this may sound like a recipe for the perfect nightmare. Democratic decision-making runs constantly risk of being overturned in Strasbourg, ordinary courts are robbed of their task to settle private disputes, private autonomy is abolished.

Reality, however, is very different. The ECtHR interferes in national private laws only rarely. This is, as we just saw, not because it does not receive a sufficient number of cases on private law matters. Its involvement is limited because of an attitudinal choice: the Court varies its review activity. It applies different standards of scrutiny in private law cases, ranging from minimal, to intermediate, to searching review. The tool through which it realises this variation is the margin

\footnotetext{
64 Walter Van Gerven, 'Of Rights, Remedies and Procedures’ (2000) 37 Common Market Law Review 501. ${ }^{65}$ See Draon (n 13) (on the possibility to seek redress for the overlooking of a child's disability during pregnancy); G.B. and R.B. (n 56) (on the height of compensation awards for medical negligence); as well as the above-cited case-law on state immunity.

${ }^{66}$ See ECHR, Kosteski v. Former Republic of Macedonia App no 55170/00 (13 April 2006) (on the requirement to prove one's faith if wanting to take holidays on religious grounds) and the previously mentioned Mikulic (n 18) (on the lack of legal means to force an alleged father to undergo DNA testing in civil suits).

${ }^{67}$ Kumm, 'Who is Afraid of the Total Constitution?' (n 4).
} 
of appreciation. ${ }^{68}$ The margin of appreciation enables the Court to defer, to different degrees, assessments connected with the proportionality of state action to the Contracting Parties, notably whether a measure is necessary and strikes an adequate balance with competing rights and concerns. ${ }^{69}$ In this way, the doctrine provides a mechanism through which the Court can limit its interference in private law and the work of national institutions. Two domestic actors benefit from this: the legislature and the judiciary.

\section{A. Deference to National Legislatures (Minimal Scrutiny)}

Much of private law has a legislative pedigree. Applying the ECHR to private law therefore frequently means reviewing, and sometimes overturning, decisions made by national parliaments. Aware of the legitimacy problems this raises - I will come to them in greater detail further below -, the ECtHR often grants domestic legislatures a margin of appreciation. In this way, it avoids second-guessing the legal, ethical, and economic choices made at the national level.

The aforementioned Draon $v$. France is an illustrative example. ${ }^{70}$ The applicants were parents of a child whose disability had, due to medical negligence, not been discovered during prenatal screenings. They brought a civil action against the hospital but, during the course of the proceedings, France enacted a new law abrogating the right to get compensation for the special burden arising from having a disabled child (whilst increasing state-sponsored allowances). The legislation was introduced after a 'stormy nation-wide debate' which was triggered by a series of high awards that French civil courts had granted in such cases. ${ }^{71}$ The applicants complained, inter alia, that this violated their rights to property and to family life. While reviewing the proportionality of the reform, the ECtHR stressed that national authorities had a wide margin of

\footnotetext{
68 The doctrine has been a staple part of ECHR jurisprudence for over four decades now: see ECHR, Handyside v. UK App no. 5493/72 (7 December 1976); Sunday Times v. UK App no. 6538/74 (26 April 1979); Open Door and Dublin Well Woman v. Ireland App nos. 14234/88 e.a. (29 October 1992); Goodwin v UK App no. 28957/95 (11 July 2002); Leyla Şabin v. Turkey App no. 44774/98 (10 November 2005); Lautsi v Italy App no. 30814/06 (18 March 2011).

${ }^{69}$ Despite the longstanding interest of ECHR scholarship in the margin of appreciation, there is still no consensus on its conceptual nature. It remains unclear how exactly the doctrine operates, which consequences it carries for judicial review, and which institutions it affects. For two attempts in this direction see George Letsas, A Theory of Interpretation of the European Convention of Human Rights (Oxford University Press 2007) 80 and Andrew Legg (n 65). Although the conceptual question cannot be dealt with here in detail, the following examples from the case-law should illustrate that the margin of appreciation has an effect on how the ECtHR exercises judicial scrutiny. It allows the Court, when e.g. confronted with the question as to whether a state measure is proportionate, to choose whether to fully review the matter itself, to limit its involvement to checking the decision-making process at the national level, or to leave the substantive decision in the hands of the domestic authorities.

70 Draon (n 13).

71 ibid., para 112.
} 
appreciation as to social and economic policies, especially where these involve sensitive ethical and political issues. Because of their 'direct knowledge of their society and its needs', they were 'better placed than the international judge' to assess what was in the public interest: ${ }^{72}$

[ $] \mathrm{n}$ deciding that the costs of caring for disabled children should be borne by reliance on national solidarity, the French legislature took the view that it was better to deal with the matter through the legislation laying down the conditions for obtaining compensation for disability than to leave to the courts the task of ruling on actions under the ordinary law of liability... It is certainly not for the Court to take the place of the national authorities in assessing the advisability of such a system or in determining what might be the best policy in this difficult social sphere. This is an area where the Contracting States are to be recognised as enjoying a wide margin of appreciation. ${ }^{73}$

The Court behaved in a cautious manner. While finding that the French law could not take away the (few) compensation claims that had already been brought in court - this constituted a disproportionate restriction on the right to property -, it also found that, overall, the new system was fine. France was free to balance the concerns connected with disability and medical negligence the way it wanted. The Court did not call in question any of the economic (lower compensation awards), social (higher reliance on public funds), and institutional choices (taking away of decision-making power from ordinary courts) made by the Assemblée Nationale. In this way, it effectively left the question as to what constituted a proportionate restriction on the right to family life to the domestic political process.

A similar approach can be observed in James and Others v. UK. ${ }^{74}$ The applicants were trustees of the Westminster family which had developed a large estate in Belgravia, a district of London which had once been farmland but turned into one of the city's most sought-after residential areas. Here, as in many other parts of the UK, landowners would typically lease their land for long periods, during which the leaseholder would build a house on the property and carry the costs for its maintenance. Once the lease was over, the property with the house would go back to the freeholder. This state of affairs was widely perceived to be unfair and was, therefore, tackled by the Labour Party in the 1967 Leasehold Reform Act. The Act gave leaseholders residing in houses on long leases (over 21 years) the right to purchase the property they occupied

\footnotetext{
72 ibid., para 75 .

73 ibid., para 114.

${ }^{74}$ James and Others (n 12).
} 
for a compensation which lay far below market value. The applicants alleged a violation of their right of property.

The question the Strasbourg judges faced in James and Others is, in private laws across the world, as common as it is delicate: how should the interests of property owners and lessees (or landlords and tenants) be balanced? To what extent should the state intervene to support the leaseholder, typically the economically weaker party, and to what extent should it protect the rights of the freeholder? The case, hence, gave the ECtHR the chance to shape a socially important part of British law. The Court passed on this possibility. It stated that the UK legislature had a better knowledge of its society's needs and, therefore, had to be granted a wide margin of appreciation:

[T] he decision to enact laws expropriating property will commonly involve consideration of political, economic and social issues on which opinions within a democratic society may reasonably differ widely. The Court, finding it natural that the margin of appreciation available to the legislature in implementing social and economic policies should be a wide one, will respect the legislature's judgment as to what is 'in the public interest' unless that judgment be manifestly without reasonable foundation. ${ }^{75}$

Although a fair balance had to be struck between the interests of freeholders and leaseholders, it was 'not for the Court to say whether the legislation was the best solution for dealing with the problem or whether the legislative discretion should have been exercised in another way. ${ }^{76}$ In the end, the British law was upheld as a proportionate restriction on the right to property. However, the Court did not find that the Act had reached a convincing trade-off between the concerns of both groups; it chose to defer this issue to the national legislature instead.

Draon and James are just two out of many examples for how the ECtHR exercises lenient judicial review in its private law jurisprudence and, by doing so, accords the Contracting Parties farreaching regulatory freedom. Cases on family law are affected particularly often by such handsoff scrutiny. The Court's deferential stance here appears to be driven by the political sensitivity of some of the questions raised as well as the lack of consensus across Europe on how to resolve them. Be it same-sex adoption, ${ }^{77}$ surrogacy contracts, ${ }^{78}$ in vitro fertilisation, ${ }^{79}$ systems of

\footnotetext{
75 ibid., para 46.

76 ibid., para 51.

77 Frette (n 39).

78 Mennesson (n 38).

79 S.H. and Others (n 37).
} 
anonymous births, ${ }^{80}$ or the legal status of transsexual parents ${ }^{81}$ - the ECtHR has avoided to interfere in any of these issues. Likewise, disputes on property attract a low intensity of review. The socio-economic complexity of problems connected with adverse possession, ${ }^{82}$ lease arrangements, ${ }^{83}$ or calculations of real estate value ${ }^{84}$ seems to make the Court scale down its involvement.

\section{B. Deference to National Courts (Intermediate Scrutiny)}

Just like domestic legislatures, domestic judges are sometimes granted a margin of appreciation by the Strasbourg Court. However, the margin they receive is typically of a different, narrower kind. The ECtHR does not let national courts decide freely on how to balance particular rights and concerns, or what is and what is not necessary in a democratic society. It imposes on them what one could call, in line with French civil law, an obligation de moyen, a duty to make their best effort. ${ }^{85}$ This approach leaves the final decision on whether a particular state action is proportionate in the hands of the national judiciary. The Court, however, requires that national judges consider all aspects which are relevant for the proportionality of the measure and provide an adequate reasoning. The ECtHR's role, as a consequence, is limited to process review: it controls how domestic courts took their decision. 86

A prominent example of this approach is Von Hannover (No. 2) v. Germany. ${ }^{87}$ Two yellow-press magazines published a series of photos of Princess Caroline von Monaco and her husband during their ski holidays in Sankt Moritz. Caroline sought an injunction against the publisher, but succeeded only partly before the domestic judiciary. Before the ECtHR, she argued, as she had successfully done in the first Von Hannover case, ${ }^{88}$ that the publication violated her right to privacy. The Court agreed that there was a restriction on Article 8 ECHR and that it had to be proportionate for to be justified. Yet, instead of exercising proportionality analysis de novo, the Court referred to the national margin of appreciation and stated that:

\footnotetext{
80 Odièvre (n 34).

$81 X, Y$ and $Z$ (n 24).

${ }^{82}$ Pye (n 58).

83 James and Others (n 12). Yet, compare with Lindheim and Others (n 59).

${ }^{84}$ ECHR, Papachelas v. Greece App no 31423/96 (25 March 1999).

${ }^{85}$ Its counterpart is the obligation de résultat, which requires the accomplishing of a particular result.

86 The Court's turn to process review is a broader phenomenon which affects its entire case-law; see Janneke Gerards and Eva Brems (eds.) Procedural Review in Fundamental Rights Cases (Cambridge University Press 2017). Although occurring more frequently vis-à-vis domestic courts, it can also be applied to domestic legislatures

87 Von Hannover v. Germany (No. 2) (n 14).

${ }^{88}$ Von Hannover (n 14).
} 
Where the balancing exercise has been undertaken by the national authorities in conformity with the criteria laid down in the Court's case-law, the Court would require strong reasons to substitute its view for that of the domestic courts. ${ }^{89}$

In the following, the Court did not examine whether the national judges had struck an adequate balance between the right to privacy and freedom of press. (It had done that in the previous Von Hannover case.) Instead, it limited itself to checking whether the domestic courts had thoroughly engaged with the criteria set out in its case-law: the contribution of the pictures to a debate of general interest; the fame of the person concerned; their prior conduct; the content, form, and effects of the publication; and the circumstances in which the photos were taken. ${ }^{90}$ It concluded that the German courts had duly considered all of these points. To what which concrete conclusion they arrived was therefore irrelevant. The Strasbourg Court's role was not to remake the balancing assessment anew; it was just to review the national decision-making process.

The judgment in Palomo Sanchez and Others v. Spain draws on the same approach. ${ }^{91}$ The applicants worked as delivery men for a private company from which they were fired after circulating a caricature of the human resources manager. The dismissal was upheld by the Spanish judiciary. The Grand Chamber of the ECtHR quickly identified the main problem to lie in whether an appropriate balance was struck between the concerns of the employees (free speech) and those of the employer (dignity in the workplace). It invoked the Member States' margin of appreciation, which existed in particular where private interests had to be weighed against each other. ${ }^{92}$ It further stated that:

the Spanish courts were required to balance the applicants' right to freedom of expression, as guaranteed by Article 10 of the Convention, against the right to honour and dignity of [their employers] in the context of an employment relationship. Article 10 of the Convention does not guarantee an unlimited freedom of expression... If the reasoning of the domestic courts' decisions concerning the limits of freedom of expression in cases involving a person's reputation is sufficient and consistent with the criteria established by the Court's case-law, the Court would require strong reasons to substitute its view for that of the domestic courts. .3

89 Von Hannover (No. 2) (n 24), para 107.

90 ibid., paras 109 et seq.

${ }^{91}$ Palomo Sanchez. (n 14).

92 ibid., para 54.

93 ibid., para 57 (emphasis added). 
The paragraph closely resembles the just-cited passage from Von Hannover (No. 2). Instead of balancing the competing interests from scratch, the Court announced that it would limit itself to checking whether the reasoning of the national courts was 'sufficient and consistent' with the criteria laid down in its jurisprudence. Again, the outcome, i.e. the actual balance struck the national level, was not important. The focus lay on how that outcome was reached. In its judgment, the ECtHR held that the domestic courts took all relevant factors into account and 'carried out an in-depth examination of the circumstances of the case and a detailed balancing of the competing interests at stake'. ${ }^{44}$ Because of that - and not because this was the most just or appropriate balance between the interests of employers and employees - their decision did not constitute a disproportionate restriction of the applicants' right to free speech.

Despite the more limited decisional leeway, the consequences of judgments like Von Hannover (No. 2) and Palomo Sanchez are ultimately similar to the legislative margin of appreciation cases..$^{95}$ The ECtHR loosens its grip over a particular regulatory issue. It does not state whether the relevant private law rule or behaviour is appropriate, whether it amounts to a proportionate restriction of someone's fundamental rights, or whether it strikes an acceptable balance with the interests of all affected. Instead, it limits itself to setting out guidelines and supervising the national judiciary. ${ }^{96}$ The ECtHR appears to make use of this option in disputes in which it does not have a full grasp of the factual circumstances or it thinks that it would, compared with the domestic courts, be the less apt decision maker. National judges can, as the Court often emphasises, be 'better placed' at times: ${ }^{97}$ they are more likely to know the facts of a case and have an understanding of its political, social, or cultural context.

\section{No Deference (Strict Scrutiny)}

The foregoing may create the impression that the ECtHR's private law jurisprudence is exclusively marked by deference - it is not. Although there is a tendency at the Court to grant

\footnotetext{
94 ibid., para 74.

${ }^{95}$ For further examples, see the ECtHR's jurisprudence on child abduction: Neulinger and Shuruk v. Switzerland App no 41615/07 (8 January 2009); Sneersone and Kampanella v. Italy App no 14737/09 (12 July 2011); Raban $v$. Romania App no 25437/08 (26 October 2010); X v. Latvia App no 27853/09 (26 November 2013).

${ }^{96}$ A similar method has been adopted by the ECJ, which increasingly defers the ultimate decision on whether a Member State act is justified and proportionate to national judges while laying down how this assessment is to be made; see Zglinski, 'The Rise of Deference: The Margin of Appreciation and Decentralised Judicial Review in EU Free Movement Law' (forthcoming 2018) Common Market Law Review.

${ }^{97}$ Handyside (n 66), para 48; De Diego Nafria v. Spain App no 46833/99 (14 March 2002), para 39; Pla and Puncernau (n 19), para 46; Afansyev v. Ukraine App no 48057/06 (15 November 2012), para 71.
} 
national authorities substantial leeway in cases concerning private law, there are examples of searching proportionality review, too. Fewer cases may fall into this category, yet they are important. It is here that the Court settles itself how to balance certain private interests or which fundamental rights restrictions are necessary, instead of leaving the decision with the domestic legislature or judiciary. Let me illustrate this with a couple of decisions.

One of the most widely debated ECtHR cases from the past couple of years is Eweida and Others v. UK. ${ }^{98}$ British Airways required all their staff in contact with the public to wear a uniform and cover religious symbols. After carrying a small cross underneath her clothes for several years, Ms Eweida at some point decided to wear it openly as a sign of commitment to her faith. The airline first suspended her and, a month later, offered her an administrative post without consumer contact which she, however, declined. When the incident was reported in the media, British Airways were heavily criticised and, as a result, authorised the wearing of certain religious symbols, including the Christian cross, but refused to compensate Ms Eweida for her lost earnings.

When the Strasbourg Court received the complaint, the applicant had lost with her claim in front of the British courts. They found that the suspension imposed by British Airways, although constituting indirect discrimination on religious grounds, was a proportionate restriction aimed at communicating a particular image of the company. The ECtHR disagreed. It held that the national decisions did not strike a fair balance between the concerns at stake. ${ }^{99}$ Although there was a legitimate interest of British Airways to promote their corporate image, the national courts had accorded it too much weight. The applicant's cross was discreet and there was no sign that it had any negative impact on the company's reputation. It was obvious that the case, like Draon and James and Others, turned on a politically sensitive question. Likewise, there was no doubt that the British judiciary had, just as the domestic courts in Von Hannover (No. 2) and Palomo Sanchez, delivered well-reasoned judgments. Nonetheless, the Strasbourg Court decided to step in. It made a de novo assessment and declared what it considered to be proportionate in the case at stake, instead of granting the UK authorities deference on this question.

Pla and Puncernau v. Andorra, which was briefly discussed in Section II., is another fascinating example of such a hands-on approach. ${ }^{100}$ The case concerned a will, made in 1939 by an

\footnotetext{
${ }^{98}$ Eweida (n 44).

99 ibid., paras 93-94.

100 Pla and Puncernau (n 19).
} 
Andorran, which stipulated that her son was to inherit her assets and was, after his death, to leave them 'to a son or grandson of a lawful and canonical marriage'. When the testatrix's son died 57 years later, the applicant, his adopted child, saw his inheritance disputed as other family members argued that the testament was exclusively meant to benefit biological children. Both the High Court and Constitutional Court of Andorra sided with the defendants, basing their judgments on the legal and social context in Andorra during the 1930s. Not only was adoption practically unheard of in Andorra at that time, also did the law restrict the inheritance rights of adopted children to assets of their adoptive parents. The applicant alleged that this constituted discrimination on grounds of filiation.

The Strasbourg Court underlined that, in interpreting the testament, the domestic courts enjoyed a wide margin of appreciation as they were better placed to assess its socio-legal context and to weigh the competing rights and interests. A violation of the Convention could only occur where their assessment of the facts or of the domestic law was 'manifestly unreasonable or arbitrary'.101 Despite these gestures of deference, the Court quashed the national judgments. First, it put forward an alternative interpretation of the testatrix's will, challenging the domestic courts' finding that the word 'son' necessarily meant biological son 70 years earlier in Andorra. ${ }^{102}$ Then, it said that, in any event, due to the profound social and legal changes that had occurred over the past decades, it could not be accepted that adoptive children were deprived of their inheritance rights. Note that there could, again, be no talk of a manifestly unreasonable or insufficiently reasoned decision of the domestic courts. The interpretation of the Andorran courts was, as both the majority opinion and the dissent stressed, 'based on factual and legal elements that were duly evaluated in the light of the particular circumstances of the case'. ${ }^{103}$ Nonetheless, the Court decided to intervene and held the national decisions to be in breach of Article 14 in connection with Article 8 ECHR.

There are further examples of such hands-on review behaviour. ${ }^{104}$ In I.B. v. Greece, the Strasbourg judges held that an employee could not be fired just because he was H.I.V. positive, even if half of the company's staff protested against a continuation of his employment. ${ }^{105}$ In G.B. and R.B. v.

\footnotetext{
101 ibid., para 46.

102 ibid., para 60.

103 ibid., para 53. In his dissent, Justice Bratza states: 'While I can readily accept that one might prefer both the reasoning and the result reached by the first-instance court, I cannot accept that the decision of the appeal court may be characterised as either arbitrary or manifestly unreasonable.'

${ }^{104}$ In addition to the judgments referred to in the following, see Von Hannover (n 14); Young, James and Webster (n 32); Burghartz (n 43); Cusan and Fazzo (n 43).

105 I.B. (n 47).
} 
Moldova, they decided that awarding only $€ 600$ in non-pecuniary damages to a patient whose ovaries were removed without prior consent in a hospital violated Article 8 ECHR. ${ }^{106}$ In Karner v. Austria, they took the stance that the right to take over a deceased spouse or partner's tenancy needed to apply also to same-sex couples. ${ }^{107}$

What is noteworthy is that these judgments displaying stricter review approaches are not concentrated on a particular field or a particular set of rights. The ECtHR's choice to intensify its scrutiny seems to be essentially driven by two factors. The first is the seriousness of the fundamental rights restriction. The Court tends to take a closer look at complaints involving severe limitations on the rights and freedoms guaranteed in the ECHR. ${ }^{108}$ Where a local court persistently denies a shop assistant her right to work part-time, 109 national laws categorically deny parents the right to give their children the mother's surname, ${ }^{110}$ or procedural rules render it impossible for a man to disprove his paternity of a child, ${ }^{111}$ the Strasbourg judges will exercise strict scrutiny because of the gravity of the impediment on the applicant's rights.

The second factor is the social status of the applicant. The ECtHR is more likely - by no means certain, though ${ }^{112}$ - to exercise hands-on scrutiny where under-represented or vulnerable social groups are disadvantaged. This includes minorities such as the LGBTQ community, ${ }^{113}$ members of opposition parties, ${ }^{114}$ and people living with H.I.V., ${ }^{115}$ all of which have suffered a long history of discrimination. Likewise, it includes women who, despite forming the numerical majority, are disadvantaged legally, economically and socially across Europe. ${ }^{116}$ By taking a close look at state and private action that affects such groups negatively, the Court ensures that the concerns of those who are ignored in the political process and society at large are given consideration at the

\footnotetext{
106 G.B. and R.B. (n 56).

107 Karner (n 40).

108 This tendency seems to equally affect other parts of the ECtHR's case-law, see Janneke Gerards, 'Pluralism, Deference and the Margin of Appreciation Doctrine' (2011) 17 European Law Journal 80, at 107 et seq.

${ }^{109}$ García Mateos (n 49).

110 Mizzi (n XXX).

111 Cusan and Fazzo (n 43).

112 See notably some of the judgments on family law, such as Frette (n 39) on same-sex adoption or or X, Y and $Z$ (n 24) on the legal status of transsexual parents, where the ECtHR granted the Contracting States a wide margin of appreciation, presumably because of the political sensitivity of the subject-matters.

113 S.H. and Others (n 37); Karner (n 40).

114 Redfearn ( $\mathrm{n}$ 48). There is, of course, a certain irony to classifying the applicant, a white male Brit who is a member of the British National Party, as belonging to an under-represented social group.

${ }^{115}$ I.B. (n 47).

116 García Mateos (n 49).
} 
level of judicial review. This contributes to counterbalancing possible majoritarian biases, an approach which resembles John Hart Ely's idea of representation reinforcement. ${ }^{117}$

\section{Doing Too Little? The Legitimacy of Deference}

The ECtHR follows, as the foregoing shows, a selective approach vis-à-vis private law. Most of the time, it behaves in a cautious manner by granting domestic authorities far-reaching deference through the margin of appreciation doctrine. Some of the time, however, it increases its engagement by exercising searching scrutiny. Two opposing criticisms can be raised against this jurisprudence. The first is that the Court does too little; that it grants national authorities an undue degree of deference and thereby fails to fulfil its duty of protecting fundamental rights. The second is that the Court does too much; that it, when interfering in national rules, subverts the existing balance of interests between private actors and imposes undue restrictions on private autonomy. At the bottom of these issues lie the questions: how actively should the ECtHR engage in the sphere of private law? And what should its impact be? The latter concerns the substantive issue as to what kind of private law we want (and will be addressed in Section VI.). The former, by contrast, concerns the institutional side, i.e. which actor we want this private law to be shaped by - here, the process of constitutionalisation pulls private law into some broader constitutional debates which I shall turn to now.

\section{A. The ECtHR and Democratic Governance}

The margin of appreciation doctrine, and deference more in general, have a bad name in human rights scholarship. ${ }^{118}$ They are said to lead to moral and cultural relativity. ${ }^{119}$ The margin of appreciation was called a 'Trojan horse' 120 which 'jeopardizes' the rights and freedoms guaranteed by the ECHR. ${ }^{121}$ Eyal Benvenisti warned that, if 'applied liberally', it can 'undermine seriously

\footnotetext{
${ }^{117}$ John Hart Ely, Democracy and Distrust (Harvard University Press 1980).

${ }^{118}$ Two notable exceptions are Andrew Legg (n 65) and Aileen Kavanagh, 'Defending Deference in Public Law and Constitutional Theory' (2010) Law Quarterly Review 222.

${ }^{119}$ James A. Sweeney, 'Margins of Appreciation: Cultural Relativity and the European Court of Human Rights in the Post-Cold War Era' (2005) 54 International and Comparative Law Quarterly 459.

${ }^{120}$ De la Rasilla del Moral (n 65).

${ }^{121}$ Feingold (n 65) at 95.
} 
the promise of international enforcement of human rights'.122 T.R.S. Allan went as far as suggesting that it 'amounts to an abdication of the judicial role'.123

Constitutional theorists may find this extreme emphasis on judicial control baffling. They have, for the best part of the $20^{\text {th }}$ century, grappled with a legitimacy problem called the 'countermajoritarian difficulty':124 to what extent and under which circumstances should a handful of unelected judges be allowed to overturn decisions of a democratic majority? Modern constitutions - the ECHR, despite being an international treaty, is no different in this respect ${ }^{125}$ are committed to both democratic governance and constitutional review. This, on the one hand, gives constitutional courts the important task of supervising the state's compliance with the provisions of the constitution. On the other, it requires them not to infringe on the powers and responsibilities of the legislative branch. How to best reconcile these two desiderata and, in particular, how to ensure that the constitutional judiciary does not overstep its function when reviewing acts of legislation, has been the object of considerable scholarly debate, one into which private law, which to a large extent is legislative law, is drawn as a result of being constitutionalised.

Many authors believe the solution to lie in proportionality analysis. If courts subject legislation (and state action more in general) to proportionality review, they do not overstep their legitimate role in a constitutional democracy. The argument usually comes in two forms. The first route is to downplay the impact of proportionality on policy making. Take the following passage from a recent article by Oliver Gerstenberg on the ECJ's jurisprudence on consumer law, responding to what he calls the 'democratic objection' to the constitutionalisation of EU private law:

\footnotetext{
122 Eyal Benvenisti, 'Margin of Appreciation, Consensus, and Universal Standards' (1999) 31 International Law and Politics 843 , at 844 .

123 T.R.S. Allan, "Human Rights and Judicial Review: A Critique of "Due Deference" (2006) 65 Cambridge Law Journal 671, at 680 .

${ }_{124}$ Alexander M. Bickel, The Least Dangerous Branch: The Supreme Court at the Bar of Politics (Bobbs-Merrill 1962); Ely (n 113); Laurence H. Tribe, 'The Puzzling Persistence of Process-Based Constitutional Theories' (1980) 89 Yale Law Journal 1063; Bruce Ackerman, 'Beyond Carolene Products' (1985) 98 Harvard Law Review 713; Jeremy Waldron, Law and Disagreement (Oxford University Press 1999); Mark Tushnet, Weak Courts, Strong Rights (Princeton University Press 2008).

${ }_{125}$ While promoting 'effective political democracy' (Preamble) and a 'democratic society' (Articles 8 to 11), the ECHR is centrally premised on judicial review, with Contracting States obliged to put legal mechanisms in place through which individuals can complain about fundamental rights violations. At its apex stands the ECtHR, acting as a supervisory body. When the Court finds domestic laws to be in violation of the Convention, it may, formally speaking, only declare them incompatible with an international treaty. In practice, however, its rulings mean that the legislature's position is effectively overturned.
} 
The Court exerts its role not so much by pushing Member States in directions they may not be prepared to go, but rather by acting as an instigator and non-dictatorial overseer of an ongoing discussion among multiple stakeholders (among whom state actors hold no privileged position) in a process of gradual interpretive clarification... Proportionality analysis becomes a process of discursive benchmarking and collaborative governance. As the process moves along over successive references, the decentralised application of general criteria opens the opportunity for their (upward) revision. At subsequent stages, as a fuller understanding of a regulatory problem emerges, the Court may intensify its powers of review and demand compliance with an emergent best-practice consensus without, however, claiming a door-closing last word. ${ }^{126}$

Gerstenberg presents proportionality as a dialogue. When a court like the ECJ or the ECtHR reviews the proportionality of a national private law rule, it does not, so his claim goes, stipulate a specific outcome. It merely sets a 'discursive benchmark' in a conversation with national authorities.

The dialogue account correctly points out the involvement of different actors in the shaping of law and policy in complex systems like the EU or the Council of Europe. ${ }^{127}$ Yet, it seriously underestimates the effects of proportionality analysis. Proportionality does not just give courts the possibility to voice an opinion in a discussion with other institutions which may or may not stick. It allows them to settle a particular issue or, to put it in Gerstenberg's terms, 'close the door'. Think of some of the examples we just came along in the ECtHR's case-law. As a private individual or company in Europe, you cannot make someone take off their religious symbol at work if it is small-sized, condition inheritance upon your heir being born from catholic marriage, or fire someone just because they have H.I.V. The idea of conversation is out of place here. There is no backtalking: the Court's proportionality ruling creates hard obligations with which the Member States of the Council of Europe must comply.

The second variant of the proportionality argument, therefore, goes in the opposite direction. It says: proportionality does have a definite impact on legislation and policy making, but that is a good thing. Mattias Kumm has, in reminiscence of John Rawls, called proportionality a publicreason test as it provides 'a checklist of individually necessary and collectively sufficient criteria'

${ }^{126}$ Gerstenberg, 'Constitutional Reasoning in Private Law - The Role of the ECJ in Adjudicating Unfair Terms in Consumer Contracts' (n 8), at 620.

127 Although the two systems differ in some regards, notably the preliminary reference mechanism, they share one important commonality: the involvement of multiple actors, legislative and judicial, at different levels in the decision-making process. 
- the four prongs or limbs - 'that need to be met for behaviour by public authorities to be demonstrably justified in terms of reasons that are acceptable in a liberal democracy.' ${ }^{28}$ If that is true, there may be nothing wrong with a constitutional court overriding a legislative act which does not meet these criteria. Quite the opposite. Where the ECtHR holds a private law rule to disproportionately restrict fundamental rights, this could mean that 'the private law discipline occupied with its internally generated occupations and distinctions - has failed to be responsive to legitimate concerns and societal shifts'. ${ }^{129}$

The 'public-reason test' account provides a more realistic portrayal of the content of proportionality analysis, yet, and this is crucial, it does not make the issue of deference disappear. From the claim that proportionality is an attractive tool for constitutional review, as it contains a set of requirements which every legislative act should be evaluated against, does not follow that the ECtHR should make use of the test in a static way. ${ }^{130}$ Courts do not operate in an institutional vacuum. They share the constitutional landscape with other actors, whose competences and duties, strengths and weaknesses need to be taken into account ${ }^{131}$ - this goes for proportionality scrutiny as much as it goes for constitutional review more in general. Add to the calculus that the ECHR is a multi-level system committed to subsidiarity, a principle requiring a certain degree of respect for the regulatory choices of the Contracting States. This may warrant that the Strasbourg judges limit their intensity of scrutiny in some situations, when they feel less capable (e.g. due to a lack of necessary expertise) or legitimate to decide on a subject-matter than the domestic political branches (e.g. when their intervention would nullify a sensitive, democratically-reached decision). Deference doctrines like the margin of appreciation are one way in which this can be achieved. ${ }^{132}$

\footnotetext{
${ }^{128}$ Mattias Kumm, 'Alexy's Theory of Constitutional Rights and the Problem of Judicial Review' in Matthias Klatt (ed), Institutionalized Reason: The Jurisprudence of Robert Alexy (Oxford University Press 2012) 202, at 203.

${ }^{129} \mathrm{Kumm}$, 'Who is Afraid of the Total Constitution?' (n 4), at 365.

${ }^{130}$ A point recognised by Kumm himself as well as by Alexy, on whose theory the former's account draws on; see Mattias Kumm, 'Internationale Handelsgesellschaft, Nold and the New Human Rights Paradigm' in Miguel Poiares Maduro and Loïc Azoulai (eds), The Past and Future of EU Law (Hart 2010) 106, at 117-118 and Robert Alexy, Theorie der Grundrechte (Suhrkamp 1986) 496. See also Aileen Kavanagh, 'Defending Deference in Public Law and Constitutional Theory' (2010) 126 Law Quarterly Review 222.

${ }^{131}$ Perhaps no scholar has demonstrated this so forcefully as Neil Komesar; see Imperfect Alternatives (University of Chicago Press 1994). Note, however, that already Bickel thought it essential to search for a function for courts 'which is peculiarly suited to [their] capabilities', which he saw to lie in reasoning with 'enduring principles'; see Bickel (no XXX) 24 et seq. Even Ely, in many respects an outlier in American constitutional theory argued for his representation-centred model based on judges being good at analysing 'process writ small' and, to some degree, also 'process writ large'; see Ely (no XXX) 102.

132 Alternative options would be to narrow down the scope of constitutional rights or adopt more direct forms of docket control, like the 'political question'-doctrine of the U.S. Supreme Court; see Rachel E. Barkow, 'More Supreme than Court? The Fall of the Political Question Doctrine and the Rise of Judicial Supremacy' (2002) 102 Columbia Law Review 237.
} 
When precisely the ECtHR should exercise deferential scrutiny and when, to the contrary, a more searching approach is justified, is a question going beyond the scope of this paper. The Court itself, as was shown, has adopted a set of criteria for determining the intensity of review it applies: stricter scrutiny where a right is seriously restricted or vulnerable societal groups are discriminated against, more deferential review on subject-matters which are politically delicate and on which there is no regulatory consensus in Europe. I do not claim that this is the best way to draw the line between the respective levels of scrutiny, or that the categories set out by the ECtHR do not raise questions. ${ }^{133}$ What cannot be doubted, though, is that variation there must be. Different standards of review, are, contrary to the voices demonising the margin of appreciation, not a doctrinal nuisance, but a basic constitutional necessity.

\section{B. The ECtHR and Judicial Competences}

A separate note is warranted on domestic courts. It has been stressed in national debates that giving human rights horizontal effect prompts a power shift within the judiciary. ${ }^{134}$ Civil courts to an important extent lose the competence to settle private disputes at the expense of the constitutional court, which becomes the final arbiter of private law. ${ }^{135}$ The argument can easily be translated into the ECHR context. There may be something worrying about the Strasbourg Court - a quasi-constitutional or 'transnational constitutional' court ${ }^{136}$ - assuming the responsibility of adjudicating on private law matters, a function in principle meant to rest with lower judiciaries in the Contracting States. It may be preferable that the ECtHR defer to national courts instead.

Typically, the objection against entrusting private law-related assessments to constitutional judges is based on the belief that there is something inherently difficult to understand about the field, something which only the ordinary judiciary can handle. It would require the special expertise of a civil court to resolve the problems that arise in private disputes and to apply the norms intended

133 Just to name a couple: why does the existence of regulatory consensus matter for the intensity of review, and can it be dangerous in situations where minorities are discriminated across Europe? Is it justified, perhaps even warranted, to intervene even in politically delicate matters in the face of gross fundamental rights violations? Likewise, must deficits of the ECtHR on a level of expertise be disregarded when serious fundamental rights problems arise?

134 Oliver Gerstenberg, 'Private Law and the New European Constitutional Settlement' (2004) 10 European Law Journal 766.

135 Kumm, 'Who is Afraid of the Total Constitution?' (n 4).

136 Alec Stone Sweet, 'On the Constitutionalisation of the Convention: The European Court of Human Rights as a Constitutional Court' (2009) Yale Law School Faculty Scholarship Series Paper 71, at 14. 
for them. It has been pointed out in the literature that this point is an exaggeration. For one thing, there is little to suggest that private law is harder to grasp than areas such as tax, administrative, or labour law, over which constitutional judges exercise scrutiny on a regular basis. ${ }^{137}$ For another, given its prominent role in both law school curricula and legal practice, many constitutional judges are likely to have received substantial training in and acquired experience with private law. ${ }^{138}$

Regardless of this, there are good reasons for the ECtHR to accord the domestic judiciary a margin of appreciation in some of its private law cases. Judicial review, especially where done through proportionality analysis, strongly relies on information. It requires gathering knowledge about 'adjudicative facts', i.e. such related to the concrete dispute at hand, as well as 'socioeconomic facts', i.e. the broader social, political, and cultural context. ${ }^{139}$ The ECtHR will, in comparison to national courts, often be disadvantaged in relation to both. A lower-instance civil judge normally comes in contact with the parties, has direct exposure to witnesses, and is located in proximity to the relevant events. The Strasbourg judges have none of that. ${ }^{140}$ The problem is exacerbated as the ECtHR is removed from the disputes brought before it not only geographically, but also in spirit. It will struggle at times with fully understanding their sociocultural dimension, especially where cases turn on local particularities. ${ }^{141}$

Against this background, deferring elements of justification and proportionality review to domestic courts can bring palpable benefits in situations in which the ECtHR indeed thinks, as the oft-repeated formulation goes, that the latter are 'better placed' to assess the facts of a dispute and to strike a balance between the relevant rights and interests. This is especially so where

\footnotetext{
137 ibid., at 364 .

${ }^{138}$ Hugh Collins speculates that this may hold true only for supreme court judges in common law countries, who are well-versed in private law, but not to constitutional court judges in continental Europe, who tend to have a public law background; Collins (n 25) 26.

139 A distinction introduced by Rasmussen, On Law and Policy in the European Court of Justice (Nijhoff 1986) 428.

140 This information imbalance is the part of the reasons for why most national high courts have adopted doctrines limiting the degree to which they review the assessments done by lower courts. In the U.S., findings of lower courts on points of law are subjected to de novo review, whereas findings on factual matters just receive deferential scrutiny; see Pullman-Standard v. Swint 456 US 273 (1982), at 288. The ECJ has developed a similar approach; see Case 6/64 Costa v E.N.E.L. [1964] ECR 585, at 593; Case C-142/05 Mickelsson and Roos [2009] ECR I-4273, paras 40-41. The German Federal Constitutional Court has clarified that it is not a Superrevisionsinstanz (super-appellate court), meaning that it does not re-assess the application of statutory law by lower courts but limits itself to reviewing whether constitutional provisions are violated; see BVerfGE, Lüth (n 29) at 207.

${ }^{141}$ Note that the ECtHR is not alone in this. The ECJ faces the exact same problems and has chosen, just like the Strasbourg court, grant substantial deference to national courts in situations in which it does not understand the factual or socio-political context; see ECJ, Case C-405/98 Gourmet International [2001] ECR I-1795.
} 
national judges apply the criteria set out in the ECtHR's case-law (or adopt convincing ones themselves) and provide a reasoning that engages with these in a satisfying way. For the Strasbourg Court, doing little in these cases may ultimately mean doing better: deference to the domestic judiciary will lead to more accurate and context-sensitive factual findings, without a lowering of the level of fundamental rights protection.

Judgments such as Von Hannover (No 2) illustrate this. ${ }^{142}$ In the proceedings at the national level, the German courts had, closely following the guidelines from the first Von Hannover case, provided a detailed analysis of all the factors which the ECtHR deemed relevant for the proportionality of an injunction. They looked into the significance of the photographs for public debate, the conduct of Princess Caroline and her family, the circumstances in which the pictures were taken, as well as the form and effects of the publication. On all of these points, they had because of speaking the local language, knowing the relevant tabloids and their social power, having a sense for the significance of the Von Hannovers' holiday activities for public debate in Germany - a better understanding than their Strasbourg counterparts or, at least, were able to gather the necessary information more easily. Deferring to the findings of the domestic judiciary under these circumstances may have not only had the advantage of ensuring a better knowledge of the factual basis of the dispute, it did no harm to the protection of the applicant's rights, which corresponded to that envisioned by the ECtHR.

\section{Doing Too Much? The Evolution of Private Law}

Let me come to the reverse problem: does the ECtHR perhaps actually intervene too strongly in national private laws? This objection can notably be raised against the cases in which the Court exercises strict scrutiny. It is here that the European judges get actively involved in the shaping of private law. It is here, in other words, that they 'do substance': 143 remake the policy judgments underlying the given subject-matter, strike a balance between the competing concerns at stake, and thus define the rights and obligations in private relations. The vision of private law advanced

142 The same goes for the previously discussed decision in Palomo Sanchez, where the Spanish labour courts subjected the dismissal of the employees to proportionality review, examining the meaning of the caricatures drawn, the gravity of the words and pictures used, and the implications these would have for the working climate within the given company - again, issues on which they had better insight than the ECtHR. Although there had been no clear European precedent on this particular issue, the aspects addressed in the local courts' decisions would have likely constituted the main elements in the ECtHR's analysis as well.

${ }^{143}$ Neil Komesar, Imperfect Alternatives (University of Chicago Press 1994) 213. 
by the Court is marked by two features: a tendency to protect the weaker party and the expansion of the idea of private autonomy.

\section{A. Weaker-Party Protection}

Who profits from the application of fundamental rights to private law is not an easy question. A priori, there seems to be no reason why the answer should depend on who is powerful and who is not, or which party has a good and which a bad bargaining position. Constitutional review creates the possibility of striking down private law rules, but it does not seem to be skewed by definition in favour of a particular social or professional group. Therefore, scholars have hypothesised that the constitutionalisation of European private law would benefit businesses as much as it benefits consumers, landlords as much as it does tenants, and employers as much as it does employees. ${ }^{144}$ Call this the neutrality thesis.

The neutrality thesis is conceptually sound. It is certainly true that, in theory, subjecting private law to fundamental rights review need neither necessarily result in a liberalisation nor in a socialisation of it. It could, in some cases, work to the advantage of the affluent and better represented (e.g. by overturning restrictions on the use of property) while, in others, profit the economically and politically less strong (e.g. by annulling standard terms that excessively burden consumers). However, this balanced picture does not align with the ECtHR's practice. To be sure, the Court occasionally does protect big landowners against their lessees. ${ }^{145}$ Or it defends the concerns of employers against those of their employees. ${ }^{146}$ But these cases are exceptions. Most of the time, when the Court chooses to intervene in national rules, the outcome is tilted towards what in private law parlance is called the 'weaker party'. It entails a curtailing of how far private individuals can be targeted by the media, ${ }^{147}$ limitations on what employees can be fired or sanctioned for, ${ }^{148}$ and an expansion of the rights of tenants against their landlords ${ }^{149}$ or patients against their doctors. ${ }^{150}$ The Court in these cases strengthens the legal position of those who, due to their lower economic, social, or educational status, have difficulties in negotiating or

\footnotetext{
${ }^{144}$ Collins (n 25) 55; Kumm, 'Who is Afraid of the Total Constitution?' (n 4$) 363$.

145 Lindheim and Others (n 59).

146 Fuentes Bobo (n 144).

147 Von Hannover (n 14).

148 Young, James and Webster (n 32); Eweida (n 44); I.B. (n 47).

149 S.H. and Others (n 37).

${ }^{150}$ G.B. and R.B. (n 56).
} 
enforcing an advantageous position for them. It does so by imposing restrictions on the principle of freedom of contract.

One would err in denouncing the ECtHR's jurisprudence because of this tendency as opposed to, or even incompatible with, the nature of private law. Not only is weaker-party protection in line with recent adjudicative trends across the continent - a comparative study in ten European countries has identified similar patterns at the national level151 -, it mirrors a more general development in private law. ${ }^{152}$ With time, it has become apparent that, if left unregulated, certain legal relations tend to produce socially unfair outcomes. Consumer contracts are a paradigm example. Because of the asymmetry in information, financial strength, and legal expertise between businesses and their customers, the latter frequently enter into arrangements which are disadvantageous for them. To counterbalance this, regulators across the globe have, roughly speaking since the 1970s, started to introduce safeguards aiming at protecting the consumer: mandatory information requirements, cooling-off periods, cancellation rights, and the like. Other areas have followed suit. The result of this development is that 'freedom of contract no longer is the sole paradigm of contract law', as Ewoud Hondius so aptly concluded; 'in the $20^{\text {th }}$ century, it has gained the company of an often opposing paradigm, that of protecting the weak party'. ${ }^{153}$

This tendency or 'bias' in the Court's case-law is a reminder of the transformative force the constitutionalisation process can have on private law. Modern debates on horizontal effect, both at the national and international level, tend to focus on the theoretical consequences that follow from applying fundamental rights to private law. They tackle problems such as the differences between direct and indirect horizontal effect, and discuss the suitability of proportionality analysis for resolving private disputes. What is lost in these discussions is that, in many countries, the initial drive to apply fundamental rights to private relations was not a theoretical, but an ideological one. It was motivated by the desire to make the law more just: to help women earn as much as men, to protect members of religious or political minorities against discrimination,

${ }^{151}$ Gert Brüggemeier, Aurelia Colombi Ciacchi and Giovanni Comandé (eds.), Private Law in the European Union (Cambridge University Press 2010). See Colombi Ciacchi’s concluding remarks at 426 et seq.

152 See Tom Hartlief, 'Freedom and Protection in Contemporary Contract Law' (2004) 27 Journal of Consumer Policy 253; Hannes Rösler, 'Protection of the Weaker Party in European Contract Law: Standardized and Individual Inferiority in Multi-Level Private Law' (2010) 18 European Review of Private Law 729; Hans.-W. Micklitz, 'The Expulsion of the Concept of Protection from the Consumer Law and the Return of Social Elements in the Civil Law: A Bittersweet Polemic', (2012) 35 Journal of Consumer Policy 283; Olga Cherednychenko, 'Public Regulation, Contract Law, and the Protection of the Weaker Party: Some Lessons from the Field of Financial Services` (2014) 4 European Review of Private Law 663.

${ }^{153}$ Ewoud Hondius, 'The Protection of the Weak Party in a Harmonised European Contract Law: A Synthesis' (2004) 27 Journal of Consumer Policy 245, at 246. 
and to bolster the socio-economic position of workers. ${ }^{154}$ By intervening at the benefit of the manifold weaker parties in its jurisprudence, the ECtHR does, if to a limited extent, exactly that. It reshapes national private laws in accordance with what it believes to be a fairer arrangement between the relevant societal groups.

\section{B. The Expansion of Private Autonomy}

Intimately connected with the above is the issue of private autonomy. It has been a longstanding point of concern that applying fundamental rights to private law matters will make autonomy, the cornerstone of private law, vanish. ${ }^{155}$ In private law discourse autonomy is understood as the freedom to enter and leave legal relations or, more generally speaking, to act according to one's will. Imposing constitutional obligations on individuals, directly or indirectly, may appear problematic against this background. For one thing, it can make it impossible for people to behave in a certain way even if they want to (and existing private law permits it). Likewise, it can force them to behave contrary to their wishes in certain circumstances.

And indeed: when the ECtHR intervenes in national private law, the outcome is frequently a restriction of autonomy - at least for some. Think about the cases discussed in the previous sections. Due to the Court's jurisprudence, you can, as an employer, not fire someone because they display their religious faith in a discrete manner. As a landlord, you cannot terminate a rental agreement based on your tenant's sexual orientation. As a testator, you are forbidden to make succession dependent on whether your son's descendants are biological or adopted children. All these individuals are obstructed from acting according to their wishes and preferences. ${ }^{156}$ However, one (wo)man's loss of autonomy is another (wo)man's gain. The employee will be finally able to wear her religious attire at work (without having to fear getting fired), the same-

\footnotetext{
154 See Micklitz, 'Introduction', in Micklitz (ed), The Constitutionalization of European Private Law (Oxford University Press 2014) 1. The debate on Drittwirkung that took place in Germany from the late 1940s until the early 1970s is an excellent illustration of this. For scholars advocating direct horizontal effect, the application of fundamental rights to private relations had a clear political purpose. It was meant to promote the emancipation of women (at work and at home), strengthen the rights of workers, and fight the discrimination of those belonging to political or religious minorities. For the main positions see Hans Carl Nipperdey, 'Grundrecht und Zivilrechtsprechung' in Maunz (ed), Festschrift für Hans Nawiasky (Isar Verlag 1956) 157) and Günter Dürig, 'Grundrechte und Privatrecht' in Festschrift für Erich Molitor (Beck 1962) 17).

155 One of the first scholars to highlight this problem was Günter Dürig (n 173).

156 The claim that proportionality analysis - which is applied in all of the aforementioned ECtHR cases - will protect the traditional role of autonomy in private law as it allows recognising autonomy as valid constitutional concern and considering it in the overall balancing calculus may, therefore, be correct in theory; see Kumm, 'Who is Afraid of the Total Constitution?' (n 4) and Collins (n 25) 50. It fails, however, to capture the actual outcomes of the Court's case-law.
} 
sex couple will be able to live their relationship 'in public' (without putting their apartment at risk), and the descendant will be able to make the family choices they desire (without jeopardizing his children's inheritance). For these parties, the judgments of the Strasbourg Court result in an increase in autonomy, and a considerable one at that. Hence, the application of the ECHR to private law matters does not change the significance of autonomy. What it changes, however, is its scope.

It would be inaccurate to call this change a shift from negative to positive autonomy or liberty, a distinction made famous by Isaiah Berlin ${ }^{157}$ and sometimes referred to in horizontal effect scholarship. ${ }^{158}$ On Berlin's account, negative liberty is the area within which individuals can act unobstructed by others, whereas the notion of positive liberty goes further and entails the desire of a person to be the instrument of their own, not of other people's, will. ${ }^{159}$ The jurisprudence of the ECtHR does not depart from the idea of negative autonomy so understood. The Court remains primarily concerned with people being able to act in a certain way without being hindered by others. It defends employees, tenants and customers against restrictions on what they can say, what they can wear, and how they can express their religious or political views. The Court's jurisprudence just expands which aspects of negative autonomy count. The unrestricted freedom to enter into and withdraw from a contract (or another legal relationship) stop being the sole focus. Other elements of autonomy, which have traditionally been less prominent in private law, are given equal importance: the possibility to exercise free speech, religious freedom, one's sexual orientation, and many more. The result is a fuller concept of negative autonomy.

Critics of the growing influence of the EHCR and constitutional rights over private law will see their concerns confirmed. The application of fundamental rights alters, even if does not eliminate, the classical role of autonomy. This conclusion, however, may not as problematic as it might initially look. Agreed: fundamental rights move private law away from autonomy in the sense of being free to interact with whom and how one wishes. Yet, private law itself has moved away from this idea too since the end of the $19^{\text {th }}$ century. ${ }^{160}$ In his seminal paper 'Three Globalizations of Law and Legal Thought', Duncan Kennedy calls this development the turn

\footnotetext{
${ }^{157}$ Isaiah Berlin, 'Two Concepts of Liberty' in Berlin, Four Essays on Liberty (Oxford University Press 1969).

${ }^{158}$ Collins (n 25), at 59 et seq.

159 Berlin (n 176).

160 The starting point for this development is considered to lie in the encyclical 'De Rerum Novarum' from 1891, in which Pope Leo XIII argued for the necessity of introducing certain social rights for workers; see Hans Micklitz, 'The Constitutional Transformation of Private Law Pillars through the ECJ' in Collins (ed.) European Contract Law and the Charter of Fundamental Rights (Intersentia 2017) 49.
} 
towards 'the Social'. ${ }^{161}$ Kennedy explains how the socio-economic consequences of the industrial revolution, including mass poverty, child labour, and abhorrent working conditions, led to a rethinking among lawyers and law makers. Instead of focusing on free will, legal thinking became increasingly preoccupied with social justice, social welfare, and social rights. The result was largescale labour legislation, the regulation of financial markets, and the introduction of protective mechanisms tenants could rely on against their landlords. ${ }^{162}$ The heyday of 'the Social' may be over; on Kennedy's account, it lasted until 1968. Its repercussions are, however, still palpable. Albeit with variations, ${ }^{163}$ the private laws of Europe remain filled with provisions that protect employees vis-à-vis employers, tenants vis-à-vis landlords, and women vis-à-vis men. They substantially limit who can, in private law, agree to what and act in which manner. One of the main drivers - some may think paradoxically, given its reputation for having a strong neoliberal bias - is the EU. It has introduced far-reaching legislation on consumer protection as well as measures aiming at eliminating discrimination in the workplace. ${ }^{164}$ Against this background, the practice of the ECtHR of restricting autonomy at the benefit of social considerations, and thereby creating new social rights, ${ }^{165}$ is not an affront to the foundations of private law. It is perfectly in line with the evolution the field has experienced.

\section{Concluding Remarks}

Although the ECtHR has created doctrinal tools allowing it to review large parts of domestic private law, it intervenes only on selected occasions. This has to do with an attitudinal choice: the Strasbourg judges often grant national authorities substantial deference and, in this way, limit their impact on the private laws of the Contracting States. Where, however, the Court chooses to intensify its scrutiny and get more actively involved, it leaves a veritable mark on private law.

\footnotetext{
${ }^{161}$ Duncan Kennedy, 'Three Globalizations of Law and Legal Thought: 1850-2000', in Trubek and Santos (eds.) The New Law and Economic Development: A Critical Appraisal (Cambridge University Press 2006). 162 ibid., 38.

163 Thomas Wilhelmsson, 'Varieties of Welfarism in European Contract Law' (2004) 10 European Law Journal 712.

${ }^{164}$ For consumer protection, see Directives 85/577/EEC (doorstep selling), 93/13/EEC (unfair contractual terms) and 97/7/EC (distance contracts), which have now been merged into the Directive on Consumer Rights 2011/83/EC. For anti-discrimination, see Directives 2000/43/EC (race equality) and 2000/78/EC (equal treatment in employment). There are, despite of these measures, recurring claims that the EU be even more active when it comes to social justice in private law; see 'Social Justice in European Contract Law: A Manifesto' (n 157).

165 This aligns with the findings in Mark Tushnet, "The Issue of State Action/Horizontal Effect in Comparative Constitutional Law' (2003) International Journal of Constitutional Law 79. Tushnet claims that countries with a strong social rights culture will find it easier to accept horizontal effect of fundamental rights than those with weakly developed social rights.
} 
It increases weaker-party protection and expands the range of autonomy-related concerns to be taken into account, thereby reshaping the rights and obligations of individuals towards each other.

This mixed approach - hands-off most of the time, hands-on some of the time - may seem contradictory. Yet, it is, as this paper sought to show, grounded in considerations from constitutional and private law theory. The Strasbourg Court faces a challenging task. It must respect the competences of national authorities, legislative and judicial, while not denying its own responsibilities as chief protector of fundamental rights in Europe. Likewise, it must take freedom of contract and autonomy seriously, while not neglecting the evolution of private law. It is because of these tensions that the Court restricts its involvement, without completely forsaking the possibility to exercise a corrective influence.

The jurisprudence of the ECtHR also teaches us a more general lesson about the constitutionalisation of private law. The application of fundamental rights to private law has been opposed by many. Not only would it result in a dangerous power shift towards constitutional courts, it would also remove the autonomy of private law. The Strasbourg Court's case-law shows that worries of this kind will frequently be exaggerated. The effect of fundamental rights on private law can, on paper, easily look strong, even 'total'. ${ }^{166}$ Yet, their actual impact will crucially depend on the approach taken by the court in charge. Therefore, asking whether fundamental rights have horizontal effect - and whether it is direct, strong indirect, or weak indirect - can be but a preliminary inquiry. More important is what courts actually make of this theoretical possibility.

It might be worthwhile to revisit the private law jurisprudence of the other European court, the ECJ, with these considerations in mind. During the past four decades, the Court of Justice has rendered a number of landmark judgments in relation to constitutional aspects of private law. Many of them attracted criticism, some were even met with outright rejection - prominent examples include Mangold (age discrimination), Viking Line (industrial action), and Test-Achats (gender equality in insurance policies), all critiqued for representing an undue degree of judicial activism on the ECJ's part. ${ }^{167}$ With subsequent debates mainly focused on the all-or-nothing question as to whether EU constitutional rights should or should not apply against private

\footnotetext{
${ }^{166} \mathrm{Kumm}$, 'Who is Afraid of the Total Constitution?' (n 4).

167 ECJ, Case C-144/04 Mangold [2005] ECR I-9981; Case C-438/05 Viking Line [2007] ECR I-10779; Case C236/09 Test-Achats [2011] ECR I-773.
} 
parties, it went largely unnoticed that the Court has in fact adopted a nuanced approach vis-à-vis private law. While taking an active stance on matters like nationality, gender and age, it exercises more lenient scrutiny in other areas through deference techniques strongly resembling those of the ECtHR. In Ariq, when interpreting the implications of the Unfair Terms Directive for consumer mortgage contracts, the Luxembourg judges left the ultimate responsibility for assessing the fairness of the relevant national rules in the hands of the domestic judiciary. ${ }^{168}$ In Achbita, they deferred the decision on whether a company could restrict the wearing of religious headscarves by its employees to the referring court, while emphasising the Member State's margin of appreciation to regulate the issue. ${ }^{169}$ Judgments like these suggest that the ECJ's caselaw on private law is more varied and, thus, less activist than it may initially appear.

This paper leaves many difficult follow-up problems unsolved. Well and good, deference must play an important role in the ECtHR's private law jurisprudence, but when exactly is a deferential approach of the Court warranted? Can it be misguided in certain circumstances? Only serious normative inquiries into the margin of appreciation doctrine, going beyond the mere collection of case-law patterns, can deliver answers here. They require tackling some tough questions, such as whether the intensity of fundamental rights review should depend on regulatory consensus, the factual expertise of the Court, or the political sensitivity of a subject-matter, and how much weight is to be attributed to process as opposed to outcome. In addition, there is the issue of an attractive vision of private law. If ECtHR decisions are meant to be more than an ad hoc resolutions of private law conflicts, they need a broader substantive foundation. What should be the overarching principles of European private law? To what degree should it remain marked by a libertarian view of private autonomy, how far should it serve as an instrument for social regulation?

${ }^{168}$ ECJ, Case C-415/11 Aziz [2013] ECR I-0000. It is important to note that the ECJ formally did not apply fundamental rights in this judgment, even if its analysis is deeply marked by fundamental rights-related considerations in substance.

169 Achbita (n 3). 